\title{
WATER PURIFICATION FROM ORGANIC CONTAMINANTS BY AVALANCHE STREAMER DISCHARGE
}

(C) 2017

Kuhno Andrey Valentinovich, postgraduate student of Engineering Ecology and Labor Safety Department

Makal'skij Leonid Mikhailovich, candidate of technical sciences, senior researcher, associate professor of Engineering Ecology and Labor Safety Department

National Research University «Moscow Power Engineering Institute» (Moscow, Russian Federation)

Tsekhanovich Olga Mikhailovna, candidate of technical sciences, associate professor of Socio-Cultural Activities and Tourism Department

Gzhel State University (Electroizolyator, Ramensky District, Moscow Region, Russian Federation)

Abstract. The paper deals with the influence of avalanche streamer discharges on aqueous solutions of organic substances such as phenols, methyl-orange and simulating amino acid and protein compounds. Studies have shown the possibility of universal water purification when using gas-discharge decontamination technologies. Complex impact of discharge phenomena, physical and chemical factors, radiation at different frequencies of avalanche streamer discharge lead to degradation of organic and inorganic substances in water impurities. The most frequently used discharges for water purification are electrolyte (discharge in liquid), glow, corona, microwave-frequency discharge excitation in several $\mathrm{GHz}$, barrier discharge and avalanche streamer discharge. It is shown that application of avalanche streamer discharges allows to undertake the decomposition of organic matter in water with decomposition in carbon compounds, gaseous components and water more efficiently and with low cost energy. Applying of a discharge technology is a promising direction of water treatment and industrial wastewater disposal technology development. Energy electric shock changes chemical characteristics of the treated water, affects its Ionic composition, structure of dissolved organic matter, viability of the microorganisms in water without additional chemical reagents.

Keywords: organic substances; water purification; discharge technologies; avalanche streamer rank; lowtemperature plasma; destruction of organic substances; industrial wastewater; aqueous solutions of organic substances; carbon compounds; phenol; methyl-orange; small-angle optical method for measuring dimensions.

УДК 581.412

\section{ДРЕВЕСНЫЕ РАСТЕНИЯ В УЛИЧНОМ ОЗЕЛЕНЕНИИ ПОСЕЛКА ГОРОДСКОГО ТИПА АЛЕКСЕЕВКА (САМАРСКАЯ ОБЛАСТЬ)}

(C) 2017

\author{
Макарова Юлия Владимировна, кандидат биологических наук, \\ старший преподаватель кафедры экологии, ботаники и охраны природы \\ Корчиков Евгений Сергеевич, кандидат биологических наук, \\ доцент кафедры экологии, ботаники и охраны природы \\ Прохорова Наталья Владимировна, доктор биологических наук, \\ профессор кафедры экологии, ботаники и охраны природы \\ Самарский национальный исследовательский университет имени академика С.П. Королёва
} (2. Самара, Российская Федераиия)

Аннотация. В статье представлены результаты изучения видового состава древесных растений, встречающихся в уличных зеленых насаждениях на территории поселка городского типа Алексеевка городского округа Кинель Самарской области. Установлено, что к числу древесных растений относится 68 видов из 48 родов, 21 семейства, 2 классов (Pinopsida, Magnoliopsida) и 2 отделов (Pinophyta, Magnoliophyta). Значительная часть этих растений (49 видов, $72,1 \%$ ) является интродуцентами, которые по своему географическому происхождению связаны с евразиатским, европейско-американским и европейским типами ареалов. Наиболее широкое распространение на улицах поселка получили представители семейства Rosaceae (21 вид, $30,9 \%$ ), а самыми крупными по числу видов являются рода Populus (6 видов), Rosa (4 вида), Ulmus, Crataegus и Acer (по 3 вида). Среди древесных растений преобладают деревья (30 видов, 44,1\%) и кустарники (25 видов, $36,8 \%$ ). Это в основном летнезеленые, перекрестноопыляемые (энтомофильные) виды, мезотрофы, мезофиты, сциогелиофиты и мезотермы, плоды и семена которых распространяются животными. В уличном озеленении используется 7 раритетных видов древесных растений: Juniperus communis L., J. sabina L., Crataegus volgensis Pojark., Tamarix ramosissima Ledeb., Cotoneaster melanocarpus Fisch. ex Blytt, Populus alba L. и Salix alba L.

Ключевые слова: уличное озеленение; древесные растения; аборигенные виды; адвентивные виды; интродуценты; раритетные виды; жизненные формы растений; таксономический анализ; хорологический анализ; биоэкологический анализ; поселок городского типа Алексеевка; городской округ Кинель; Самарская область.

Поселок городского типа Алексеевка (п.г.т. Алексеевка) расположен на территории Кинельского муниципального района Самарской области. Он входит в состав г.о. Кинель и является его промышленной зоной. Населенный пункт имеет богатую историю: он был основан 28 февраля 1700 г. по указу Петра I как Алексеевская оборонительная крепость. В своем современном виде поселок находится в 15 км от 
г. Кинель и в 30 км от г. Самара. Его площадь 632 га, численность постоянно проживающего населения на 1 января 2016 г. - 11115 человек [1].

П.г.т. Алексеевка располагается в долине р. Самары, в непосредственной близости от места ее слияния с р. Большой Кинель. Грунтовые воды на территории поселка залегают в отложениях дочетвертичного возраста. По химическому составу они относятся к категории гидрокарбонатно-кальциевых, слабоминерализованных, с концентрацией солей до 1 г/л и могут безопасно использоваться для питьевых и хозяйственных нужд $[2 ; 3]$.

Рельеф поселка равнинный. Самыми молодыми дочетвертичными образованиями, участвующими в формировании рельефа, являются породы верхнего подъяруса казанского яруса пермского периода палеозойской эры (пестроцветные глины, мергели, известняки, доломиты, алевролиты, песчаники, конгломераты, гипсы, ангидриты) [4]. Они залегают близко к поверхности и перекрываются слабо развитыми отложениями четвертичного периода. В частности, северная, северо-западная, западная и югозападная части поселка, расположенные на первой и второй надпойменных террасах р. Самары, находятся на аллювиальных отложениях плейстоцена и верхнего звена неоплейстоцена (пески с гравием и галькой, суглинки, глины). Северо-восточная, восточная и центральная части расположены на нерасчлененных элювиальных и делювиальных отложениях неоплейстоцена (пески, суглинки, суглинки с дресвой и щебнем, суглинки лессовидные, погребенные почвы). Пойменная южная часть поселка лежит на сравнительно более молодых аллювиальных отложениях голоцена (пески с гравием и галькой, суглинки, глины, алевриты) [5].

П.г.т. Алексеевке присущи все характерные особенности континентального климата. Самый теплый месяц в году - июль, средняя температура которого $+20,5 \ldots+21,0^{\circ} \mathrm{C}$. При этом максимум температур может превышать $+40^{\circ} \mathrm{C}$. Сумма активных температур $2430^{\circ} \mathrm{C}$. Самый холодный месяц - январь со средней температурой воздуха $-13,0 \ldots-13,5^{\circ} \mathrm{C}$. Его температурные показатели свидетельствуют о том, что зима в Алексеевке протекает мягче, чем в населенных пунктах на юге, юго-западе, востоке, северо-востоке и севере Самарской области. В целом, среднегодовая температура воздуха в поселке составляет $+4,3^{\circ} \mathrm{C}$ $[2 ; 6]$.

Согласно агроклиматическому районированию Самарской области, Алексеевка расположена в районе пониженного увлажнения [2]. За год здесь может выпадать от 400 до 500 мм осадков, но в среднем около 430 мм. Максимум осадков (74-78 мм) приходится на июнь-август. Бывают годы, когда в течение нескольких месяцев осадков не выпадает совсем и случаются летние засухи. Первый снег отмечается в октябре. Неустойчивый снежный покров образуется к концу октября-началу ноября, устойчивый - в третьей декаде ноября. Средняя продолжительность существования снежного покрова 148-156 дней, средняя из наибольших декадных его высот 25-30 см. Снеготаяние начинается в третьей декаде марта и продолжается в течение 13-15 дней [6].

В соответствии с геоботаническим районированием Самарской области, поселок расположен на стыке двух природных зон: лесостепной зоны, для которой основным типом растительности являются лиственные леса в сочетании с разнотравно-дерновинно-злаковыми степями, и переходной (от лесостепной к степной) зоны, которой свойственны типчаково-ковыльные богаторазнотравные, мелкозлаково-богаторазнотравные и мелкозлаково-осоковые с ковылями сообщества [6]. В прошлом, в условиях слабодефицитного атмосферного увлажнения, разнотравно-злаковая растительность позволила сформироваться на месте расположения поселка типичным и типичным остаточно-карбонатным черноземам. И только в юго-западной части Алексеевки, находящейся на возвышенном участке поймы р. Самары, в условиях кратковременного увлажнения паводковыми водами сформировались аллювиальные дерновые насыщенные почвы [2; 6; 7].

Усилиями администрации г.о. Кинель и при непосредственном участии местных жителей п.г.т. Алексеевка озеленен. Зелеными насаждениями общего и ограниченного пользования занято около 100,4 га, из которых 45,1 га находятся под уличными насаждениями и 55,3 га - под внутриквартальными насаждениями. Уличные и внутриквартальные зеленые насаждения расположены на территории поселка неравномерно. Их основной объем сосредоточен в границах улиц Ульяновской, Гагарина, Невской и Зеленой, застроенных высотными зданиями. Объекты уличного озеленения в небольшом количестве встречаются и за пределами указанной территории, главным образом на улицах Фрунзе, Колхозной, Специалистов, Молодежной, Комсомольской, Братьев Володичкиных и Октябрьской. В поселке располагается 1 парк (от ул. Гагарина до пересечения с ул. Невской и ул. Луговой), 3 сквера (на пл. им. В.И. Ленина, на пл. Дружбы и между ул. Солнечной и ул. Специалистов) и 1 бульвар (на ул. Невской). Возрастное состояние деревьев свидетельствует о том, что большинство объектов озеленения создано более 30 лет назад, вследствие чего значительная часть старых генеративных стволов имеет неудовлетворительное состояние и требует замены. В целях оптимизации состояния существующих в п.г.т. Алексеевка зеленых насаждений, а также для закладки новых объектов озеленения требуется изучить видовое разнообразие древесных растений. Это особенно актуально в отношении уличных насаждений, выполняющих не только санитарно-гигиенические, но и декоративно-планировочные функции.

Обследование уличных зеленых насаждений на территории п.г.т. Алексеевка проводилось маршрутным методом в весенний и летний периоды 2014 года. При движении по маршрутам регистрировались древесные растения в имматурном, виргинильном, генеративном и сенильном возрастных состояниях. После завершения полевого этапа исследований был проведен таксономический, хорологический и биоэкологический анализ собранного фактического материала, выделены раритетные виды древесных растений. Хорологический анализ выполнен с использованием классификации ареалов Т.И. Плаксиной [8], биоэкологический анализ - с использованием систем жизненных форм К. Раункиера [9], И.Г. Серебрякова и Т.И. Серебряковой [10-12], А.Л. Бельгарда [13] в модификации Н.М. Матвеева [14]. Основные сведения о видах почерпнуты из работ [15-27]. 
Макарова Ю.В., Корчиков Е.С., Прохорова Н.В.

Проведенные исследования показали, что на улицах п.г.т. Алексеевка произрастают 68 видов древесных растений из 48 родов, 21 семейства, 2 классов (Pinopsida, Magnoliopsida) и 2 отделов (Ріnophyta, Magnoliophyta) (табл. 1). При этом отдел Magnoliophyta насчитывает 60 видов из 42 родов и 19 семейств, отдел Pinophyta -8 видов из 6 родов (Abies, Larix, Picea, Pinus, Juniperus, Thuja) и 2 ceмейств (Pinaceae, Cupressaceae).

Таблица 1 - Соотношение основных систематических групп древесных растений, используемых в уличном озеленении п.г.т. Алексеевка

\begin{tabular}{|l|c|c|c|c|c|c|}
\hline \multirow{2}{*}{$\begin{array}{c}\text { Система- } \\
\text { тическая } \\
\text { группа }\end{array}$} & \multicolumn{6}{|c|}{ Количество } \\
\cline { 2 - 7 } & семейств & \multicolumn{2}{c|}{ родов } & \multicolumn{2}{c|}{ видов } \\
\cline { 2 - 8 } & абс. & $\%$ & абс. & $\%$ & абс. & $\%$ \\
\hline $\begin{array}{l}\text { Pinophyta } \\
\text { (Pinopsida) }\end{array}$ & 2 & 9,5 & 6 & 12,5 & 8 & 11,8 \\
\hline $\begin{array}{l}\text { Magnoliophyta } \\
\text { (Magnoliopsida) }\end{array}$ & 19 & 90,5 & 42 & 87,5 & 60 & 88,2 \\
\hline Всего: & 21 & 100 & 48 & 100 & 68 & 100 \\
\hline
\end{tabular}

Ведущими по числу видов являются 5 семейств, которые объединяют $60,3 \%$ видов и $56,3 \%$ родов (табл. 2). Лидирование семейств Rosaceae и Salicaсеае обусловлено высокой декоративностью видов [Amelanchier spicata (Lam.) C. Koch, Cotoneaster melanocarpus Fisch. ex Blytt, Crataegus sanguinea Pall., C. submollis Sarg., C. volgensis Pojark., Padus virginiana (L.) Mill., Physocarpus opulifolius (L.) Maxim., Rosa gallica L., R. majalis Herrm., R. rugosa Thunb., Sorbaria sorbifolia (L.) A. Br., Sorbus aucuparia L., S. hybrida L., Populus alba L., P. italica (DuRoi) Moench, P. simonii Carr., P. suaveolens Fisch., P. tremula L., Salix alba L.], их частым использованием в местном садоводстве [Amelanchier spicata (Lam.) C. Koch, Armeniaca vulgaris Lam., Aronia melanocarpa (Michx.) Elliott, Cerasus vulgaris Mill., Malus domestica Borkh., Prunus domestica L., Pyrus communis L., Rubus idaeus L.], а также хорошей приживаемостью и быстрым ростом в климатических условиях поселка. Остальные семейства содержат по три (Aceraceae, Cupressaceae, Fabaceae, Ulmaceae), по два (Berberidaceae, Vitaceae, Tiliaceae) и по одному виду (Betulaceae, Fagaceae, Grossulariaceae, Hydrangeaceae, Anacardiaceae, Hippocastanaceae, Tamaricaceae, Elaeagnaceae, Cornaceae).

Таблица 2 - Ведущие семейства древесных растений, используемых в уличном озеленении п.г.т. Алексеевка

\begin{tabular}{|c|l|c|c|c|c|}
\hline \multirow{2}{*}{ № } & \multirow{2}{*}{ Семейство } & \multicolumn{2}{|c|}{ Число видов } & \multicolumn{2}{c|}{ Число родов } \\
\cline { 3 - 6 } & & абс. & $\%$ & абс. & $\%$ \\
\hline 1 & Rosaceae & 21 & 30,9 & 15 & 31,3 \\
\hline 2 & Salicaceae & 7 & 10,3 & 2 & 4,2 \\
\hline 3 & Pinaceae & 5 & 7,4 & 4 & 8,4 \\
\hline 4 & Oleaceae & 4 & 5,9 & 2 & 4,2 \\
\hline 5 & Caprifoliaceae & 4 & 5,9 & 4 & 8,4 \\
\hline \multicolumn{2}{|c|}{ Всего: } & 41 & 60,3 & 27 & 56,3 \\
\hline
\end{tabular}

Самыми крупными по числу видов являются рода Populus (6 видов), Rosa (4 вида), Ulmus, Crataegus и Acer (по 3 вида). Рода Picea, Juniperus, Sorbus, Tilia, Fraxinus, Syringa содержат по 2 вида. Остальные рода одновидовые.
Среди древесных растений на улицах п.г.т. Алексеевка встречаются как аборигенные, так и адвентивные виды. Аборигенная фракция представлена 19 видами (27,9\%): Pinus sylvestris L., Populus alba L., P. nigra L., P. tremula L., Salix alba L., Betula pendula Roth, Quercus robur L., Ulmus glabra Huds., U. laevis Pall., Cotoneaster melanocarpus Fisch. ex Blytt, Crataegus sanguinea Pall., C. volgensis Pojark., Rubus idaeus L., Rosa majalis Herrm., Sorbus aucuparia L., Acer platanoides L., A. tataricum L., Tilia cordata Mill., Viburnum opulus L. Они относятся к 14 родам и 9 семействам, из которых семейство Rosaceae является самым многочисленным и содержит 6 видов, семейство Salicaceae насчитывает 4 вида, Ulmaceae и Aceraceae - по 2 вида, Pinaceae, Betulaceae, Fagaceae, Tiliaceae и Caprifoliaceae - по 1 виду. В аборигенной фракции преобладают рода Populus (3 вида), Ulmus и Crataegus (по 2 вида).

Остальные виды $(72,1 \%)$ являются адвентивными, или видами-интродуцентами. Среди них Abies sibirica Ledeb., Larix sibirica Ledeb., Picea abies (L.) Karst., P. pungens Engelm., Juniperus communis L., J. sabina L., Thuja occidentalis L., Populus italica (DuRoi) Moench, P. simonii Carr., P. suaveolens Fisch., Ulmus pumila L., Berberis vulgaris L., Mahonia aquifolium (Pursh) Nutt., Grossularia reclinata (L.) Mill., Philadelphus coronarius L., Amelanchier spicata (Lam.) C. Koch, Armeniaca vulgaris Lam., Aronia melanocarpa (Michx.) Elliott, Cerasus vulgaris Mill., Crataegus submollis Sarg., Malus domestica Borkh., Padus virginiana (L.) Mill., Physocarpus opulifolius (L.) Maxim., Prunus domestica L., Rosa gallica L., R. rugosa Thunb., Sorbaria sorbifolia (L.) A. Br., Sorbus hybrida L., Caragana arborescens Lam., Gleditsia triacanthos L., Robinia pseudoacacia L., Acer negundo L., Rhus coriaria L., Aesculus hippocastanum L., Parthenocissus quinquefolia (L.) Planch., Vitis vinifera L., Tilia platyphyllos Scop., Tamarix ramosissima Ledeb., Elaeagnus angustifolia L., Swida alba (L.) Opiz, Fraxinus lanceolata Borkh., F. pennsylvanica Marsh., Syringa vulgaris L., S. villosa Vahl, Lonicera tatarica L., Sambucus racemosa L., Symphoricarpos rivularis Suksdorf. Перечисленные виды относятся к 41 роду и 19 семействам. Самое большое число видов-интродуцентов по-прежнему заключает семейство Rosaceae (15 видов). По 4 вида содержат семейства Pinaceae и Oleaceae. По 3 вида семейства Cupressaceae, Salicaceae, Fabaceae, Caprifoliaceae. По 2 вида - семейства Berberidaceae и Vitaсеае. Остальные семейства (Ulmaceae, Grossulariaceae, Hydrangeaceae, Aceraceae, Anacardiaceae, Hippocastanaceae, Tiliaceae, Tamaricaceae, Elaeagnaceae, Cornaceae) насчитывают по 1 виду. В родах Populus и Rosa по 3 вида. В родах Picea, Juniperus, Fraxinus и Syringa по 2 вида. В остальных родах по 1 виду.

Произрастающие на улицах поселка древесные растения относятся к 7 типам ареалов. Наиболее многочисленны виды евразиатского типа ареалов, распространенные в пределах европейского и азиатского континентов. К их числу относятся собственно евразиатские (Populus nigra L., P. tremula L., Salix alba L., Philadelphus coronarius L., Cotoneaster melanocarpus Fisch. ex Blytt, Pyrus communis L., Tilia cordata Mill., T. platyphyllos Scop., Syringa villosa Vahl), евразиатские бореальные (Pinus sylvestris L., Rubus idaeus L., Lonicera tatarica L.), евросибирские [Abies 
sibirica Ledeb., Larix sibirica Ledeb., Betula pendula Roth, Crataegus sanguinea Pall., Swida alba (L.) Opiz, Viburnum opulus L.], азиатские [Populus simonii Carr., P. suaveolens Fisch., Ulmus pumila L., Armeniaca vulgaris Lam., Elaeagnus angustifolia L., Sorbaria sorbifolia (L.) A. Br., Caragana arborescens Lam.] и восточноевропейско-азиатский (Rosa rugosa Thunb.) виды. В общей сложности евразиатский тип ареалов представлен 26 видами $(38,2 \%)$.

Второе место по численности занимают представители европейско-американского типа ареалов (15 видов, 22,1\%). Среди них Picea pungens Engelm., Thuja occidentalis L., Mahonia aquifolium (Pursh) Nutt., Aronia melanocarpa (Michx.) Elliott, Amelanchier spicata (Lam.) C. Koch, Crataegus submollis Sarg., Padus virginiana (L.) Mill., Physocarpus opulifolius (L.) Maxim., Gleditsia triacanthos L., Robinia pseudoacacia L., Acer negundo L., Parthenocissus quinquefolia (L.) Planch., Fraxinus lanceolata Borkh., F. pennsylvanica Marsh., Symphoricarpos rivularis Suksdorf.

Европейский тип ареалов имеют 13 видов (19,1\%). Это европейские неморальные [Quercus robur L., Ulmus glabra Huds., U. laevis Pall., Berberis vulgaris L., Grossularia reclinata (L.) Mill., Acer platanoides L., Sorbus hybrida L., Sambucus racemosa L.], европейские бореальные [Picea abies (L.) Karst., Sorbus aucuparia L.] и восточноевропейские (Rosa majalis Herrm., Acer tataricum L., Crataegus volgensis Pojark.) виды.

Представителей древнесредиземноморского типа ареалов, распространенных на территории Древнесредиземноморского подцарства или одной из его флористических областей, пять (7,4\%): Juniperus sabina L., Populus italica (DuRoi) Moench, Rosa gallica L., Vitis vinifera L., Tamarix ramosissima Ledeb. Четыре вида (5,9\%) (Populus alba L., Rhus coriaria L., Aesculus hippocastanum L., Syringa vulgaris L.) относятся к средиземноморскому типу ареалов. По 2 вида (по 2,9\%) принадлежат голарктическому и плюрирегиональному типам ареалов. Голарктическими видами, распространенными на территории Голарктического царства, являются Juniperus communis L. и Cerasus vulgaris Mill. Плюрирегиональными, встречающимися более чем на трех континентах Земного шара, - Malus domestica Borkh. и Prunus domestica $\mathrm{L}$.

Использование древесных растений в озеленении населенных пунктов определяется их биологическими особенностями. Среди наиболее значимых можно отметить следующие: способность вида переносить неблагоприятные условия климата и погоды (заморозки, морозы, зной, засуху), способность занимать определенного размера экологическую нишу в сообществе и территорию в пространстве, продолжительность вегетации, способы опыления и распространения диаспор, отношение к световому, тепловому, водному и солевому режимам биотопа. Перечисленные характеристики дают представление о степени соответствия вида условиям местопроизрастания и позволяют спрогнозировать его устойчивость на изучаемой территории.

Применение системы жизненных форм (климаморф) К. Раункиера [9], дающей представление о способности видов переносить неблагоприятные климатические и погодные условия, складывающие- ся в месте их произрастания, показало, что все анализируемые растения относятся к одной климаморфе - фанерофитам. Внутри этой группы численно преобладают мезофанерофиты (29 видов, 42,6\%), имеющие высоту более 8 м. Им уступают микрофанерофиты (23 вида, 33,8\%) и нанофанерофиты (16 видов, $23,6 \%$ ), высота которых составляет от 2 до 8 м и менее 2 м соответственно. Поэтому, принимая решение об использовании в озеленении видов, принадлежащих к тому или иному подтипу фанерофитов, следует учитывать, что чем выше растение, тем ниже его устойчивость по отношению к неблагоприятным климатическим и погодным условиям: существенно удаленные от поверхности почвы почки возобновления легче повреждаются зимними морозами, молодые листья более уязвимы для весенних и раннелетних заморозков, а в жаркий и засушливый период лета (июль-август) у таких растений более вероятен ранний листопад.

Способность занимать определенного размера экологическую нишу в сообществе и территорию в пространстве определяется, главным образом, биоморфой растения. По системе биоморф И.Г. Серебрякова $[10 ; 11]$ и Т.И. Серебряковой [12] среди изучаемых растений выделяются две группы: древесные и полудревесные растения. Среди древесных преобладают деревья (30 видов, 44,1\%) и кустарники (25 видов, 36,8\%). Видов с переходной биоморфой существенно меньше: к ним относятся 10 видов $(14,7 \%)$ с биоморфой «дерево или кустарник» и 1 вид $(1,5 \%)$ с биоморфой «кустарник или полукустарник». Группа полудревесных растений представлена деревянистыми лианами Parthenocissus quinquefolia (L.) Planch. и Vitis vinifera L. (2,9\%).

Среди древесных растений поселка превалируют летнезеленые (60 видов, 88,2\%). Другую группу по продолжительности вегетации составляют вечнозеленые растения $(11,8 \%)$, среди которых высокодекоративные Abies sibirica Ledeb., Picea abies (L.) Karst., P. pungens Engelm., Pinus sylvestris L., Juniperus communis L., J. sabina L., Thuja occidentalis L., Mahonia aquifolium (Pursh) Nutt.

Практически все анализируемые виды растений относятся к числу перекрестноопыляемых (66 видов, 97,0\%). Один вид [Parthenocissus quinquefolia (L.) Planch.] является самоопылителем с гейтоногамным перемещением пыльцы. Еще одному виду (Larix sibirica Ledeb.) свойственно и самоопыление (гейтоногамия), и перекрестное опыление (анемофилия). Среди перекрестноопыляемых растений преобладают энтомофилы (42 вида, $61,8 \%$ от всей совокупности видов). Им существенно уступают анемофилы (20 видов, 29,4\%) и анемофильно-энтомофильные виды (4 вида, 5,9\%). Следует отметить, что ветроопыляемые растения более успешны в реализации своей жизненной стратегии, чем растения, опыляемые насекомыми. Этому способствуют умеренные и сильные ветры, часто отмечаемые на территории поселка. Практически ежегодно здесь фиксируются суховейные периоды, продолжительность которых составляет в среднем 44 дня. Каждый год случаются суховеи средней интенсивности со скоростью ветра 6-9 м/с, каждый третий год - очень интенсивные суховеи со скоростью ветра более $10 \mathrm{~m} / \mathrm{c}$. При этом максимум ветреных дней (со скоростью ветра более 
15 м/с) приходится на конец апреля - май [2; 6], когда отмечается цветение у большинства видов древесных растений.

По способу диссеминации ведущую позицию занимают растения-зоохоры (31 вид, 45,6\%), распространение диаспор которых происходит с помощью животных. Участие животных в распространении семян и плодов может происходить путем эндозоохории (диаспоры поедаются, проходят через пищеварительный тракт, а затем выбрасываются с погадкой или пометом), синзоохории (диаспоры растаскиваются и складируются в гнездах или в кладовых кормов) и эпизоохории (диаспоры переносятся пассивно на поверхности тела). На улицах поселка такими животными-переносчиками являются главным образом птицы, мышевидные грызуны, муравьи, а также встречающиеся в большом количестве кошки.

К зоохорам близки по численности анемохоры (27 видов, 39,7\%), диаспоры которых распространяет ветер. Для видов древесных растений, используемых в озеленении улиц поселка, присущи три формы анемохории: анемоаэрохория (перенос диаспор по воздуху), анемогеохория (перекатывание диаспор по поверхности земли) и анемохионохория (перенос ветром по поверхности снега). Для 8 видов (11,7\%) характерна диплохория, при которой сочетаются два способа диссеминации. Для 2 видов $(3,0 \%)$ - автохория (автомеханохория и барохория) со свойственным ей распространением семян и плодов без участия сторонних агентов.

Изучение способов распространения диаспор позволяет установить скорость расселения вида по территории, а также определить долю его участия в сложении зеленых насаждений. Однако, это имеет важное значение лишь в отношении аборигенных видов, а также тех адвентивных видов, которые способны натурализоваться в местных климатических условиях. К числу последних на территории п.г.т. Алексеевка относятся Acer negundo L., Ulmus pumila L., Fraxinus lanceolata Borkh., F. pennsylvanica Marsh., Elaeagnus angustifolia L., Syringa vulgaris L., Cerasus vulgaris Mill., Prunus domestica L. и Parthenocissus quinquefolia (L.) Planch. Следует отметить, что ряд адвентивных видов, произрастающих в поселке [Acer negundo L., Fraxinus pennsylvanica Marsh., Elaeagnus angustifolia L., Sorbaria sorbifolia (L.) A. Br., Amelanchier spicata (Lam.) C. Koch, Ulmus pumila L., Caragana arborescens Lam., Robinia pseudoacacia L., Rosa rugosa Thunb., Sambucus racemosa L., Aronia melanocarpa (Michx.) Elliott, Physocarpus opulifolius (L.) Maxim.], благодаря своей способности активно размножаться и быстро распространяться во вторичном ареале признаны потенциально агрессивными по отношению к аборигенным видам [17], а значит их разведение на территории поселка рекомендуется проводить с осторожностью.

Среди древесных растений преобладают мезотрофы (47 видов, 69,1\%: Lonicera tatarica L., Syringa vulgaris L., Tilia cordata Mill., Robinia pseudoacacia L. и др.), умеренно требовательные к содержанию питательных элементов в почве. Значительно меньше мегатрофов (15 видов, 22,0\%: Populus alba L., Ulmus glabra Huds., Crataegus sanguinea Pall., Viburnum opulus L. и др.), предпочитающих высокоплодородные почвы. Крайне редко встречаются обитатели
Древесные растения в уличном озеленении поселка...

бедных, малоплодородных почв - олиготрофы $(P i$ nus sylvestris L., Betula pendula Roth, Crataegus volgensis Pojark., Sambucus racemosa L.) и солестойкие виды богатых по плодородию, но солонцеватых почв - галомегатрофы (Acer tataricum L., Tamarix ramosissima Ledeb.). Таким образом, расположенные на территории поселка черноземы типичные, черноземы типичные остаточно-карбонатные и аллювиальные дерновые насыщенные почвы чрезвычайно благоприятны для роста и развития не только олиготрофов и мезотрофов, но и весьма требовательных к содержанию питательных элементов мегатрофов и галомегатрофов. Местные типы почв высокоплодородны (валовые запасы гумуса в метровом слое колеблются от 599 до 919 т/га, содержание гумуса в верхней части гумусового горизонта составляет 7,0$10,0 \%$, гуминовые кислоты количественно преобладают над фульвокислотами, почвенно-поглощающий комплекс почти полностью насыщен ионами кальция и магния), имеют прочную зернистую структуру с доминированием тяжелосуглинистых и глинистых фракций, нейтральную или слабощелочную реакцию среды и характеризуются высокой водопроницаемостью и хорошей аэрацией $[2 ; 6]$.

Абсолютное большинство видов является мезофитами (28 видов, 41,2\%), приспособленными к жизни в среде с умеренной, но не избыточной влажностью почвы и атмосферного воздуха [Malus domestica Borkh., Padus virginiana (L.) Mill., Rubus idaeus L., Acer platanoides L. и др.]. Равное число видов (по 11, по 16,2\%) в группах ксеромезофитов (Quercus robur L., Berberis vulgaris L., Pyrus communis L. и др.) и мезоксерофитов [Ulmus pumila L., Mahonia aquifolium (Pursh) Nutt., Acer negundo L. и др.], требующих свежеватых и суховатых гигротопов соответственно. Им уступают мезогигрофиты [9 видов, 13,2\%: Populus alba L., P. italica (DuRoi) Moench, P. nigra L., P. tremula L., Betula pendula Roth, Ulmus laevis Pall., Sorbus aucuparia L., Fraxinus lanceolata Borkh., F. pennsylvanica Marsh.] - растения влажных гигротопов, и гигромезофиты [5 видов, 7,3\%: Populus suaveolens Fisch., Philadelphus coronarius L., Rosa rugosa Thunb., Sorbaria sorbifolia (L.) A. Br., Swida alba (L.) Opiz] - растения влажноватых гигротопов. Три вида (4,4\%) (Pinus sylvestris L., Juniperus sabina L., Rhus coriaria L.) являются ксерофитами - засухоустойчивыми растениями сухих гигротопов. Один вид (Salix alba L.) - гигрофит, в естественных условиях устойчиво обитающий на сырой почве. Проведенный гигроморфный анализ свидетельствует о том, что 43 вида $(63,2 \%)$ из числа используемых в озеленении улиц п.г.т. Алексеевка развиваются в условиях нехватки почвенной и атмосферной влаги (мезофиты, гигромезофиты, мезогигрофиты и, особенно, гигрофит). Для ксеромезофитов, мезоксерофитов и ксерофитов (25 видов, 36,8\%) количество влаги в почве и воздухе оптимально.

Анализ гелиоморф выявил преобладание сциогелиофитов (46 видов, 67,6\%), экологический оптимум которых находится в полуажурнокронных лесонасаждениях с полуосветленной световой структурой. Среди них Thuja occidentalis L., Mahonia aquifolium (Pursh) Nutt., Grossularia reclinata (L.) Mill., Prunus domestica L. и ряд других. Гелиосциофиты, оптимум которых находится в полуплотнокронных насажде- 
ниях полутеневой структуры, насчитывают 13 видов (19,1\%): Larix sibirica Ledeb., Padus virginiana (L.) Mill., Sorbaria sorbifolia (L.) A. Br., Gleditsia triacanthos L. и другие. Еще 7 видов (10,3\%) являются светолюбивыми растениями и растениями открытых пространств - гелиофитами: Pinus sylvestris L., Populus tremula L., Salix alba L., Betula pendula Roth, Malus domestica Borkh., Rosa gallica L., Tamarix ramosissima Ledeb. Два вида (3,0\%) [Picea abies (L.) Karst., Viburnum opulus L.] - сциофиты, экологический оптимум которых соответствует плотнокронным лесам теневой структуры.

В соответствии с температурным режимом биотопа доминируют мезотермы (52 вида, 76,5\%), эволюционное формирование которых происходило в условиях суббореального климата. К их числу относятся Juniperus sabina L., Populus alba L., Ulmus laevis Pall., Berberis vulgaris L. и другие. Формировавшиеся в бореальном климате олиготермы составляют 11 видов (16,2\%) [Abies sibirica Ledeb., Larix sibirica Ledeb., Picea abies (L.) Karst., P. pungens Engelm., Pinus sylvestris L., Juniperus communis L., Populus tremula L., Betula pendula Roth, Rosa rugosa Thunb., Rubus idaeus L., Swida alba (L.) Opiz]. Значительно реже встречаются мегатермы, эволюционно развивавшиеся в субтропическом климате (Armeniaca vulgaris Lam., Robinia pseudoacacia L., Aesculus hippocastanum L., Vitis vinifera L., Tamarix ramosissima Ledeb.) (7,3\%). Рост последних на территории поселка сдерживается раннелетними заморозками и малой мощностью снежного покрова поздней осенью.

В составе рядовых и групповых посадок с участием разнообразных древесных растений отмечено 7 раритетных видов, 6 из которых охраняются на региональном уровне. Это крайне редкие для Самарской области Juniperus communis L., J. sabina L., Crataegus volgensis Pojark., Tamarix ramosissima Ledeb. и условно редкие Cotoneaster melanocarpus Fisch. ex Blytt и Populus alba L. [15]. Crataegus volgensis Pojark. является средневолжским эндемиком, Juniperus sabina L. - палеоген-неогеновым горностепным реликтом. Еще один вид - Salix alba L. включен в список редких и уязвимых таксонов, нуждающихся в постоянном контроле и наблюдении на территории Самарской области [15]. В уличных зеленых насаждениях перечисленные виды встречаются достаточно редко, что обусловлено их узкой экологической амплитудой и ограниченным числом подходящих мест произрастания.

Таким образом, выявлен и проанализирован видовой состав древесных растений, входящих в состав уличных зеленых насаждений п.г.т. Алексеевка Самарской области. Дальнейшее изучение внутриквартальных объектов озеленения общего и ограниченного пользования позволит расширить представление о разнообразии древесных растений на территории поселка, что может найти практическое применение при разработке проектов озеленения и при проведении мероприятий, направленных на оптимизацию существующих зеленых насаждений на территориях населенных пунктов городского типа.

\section{СПИСОК ЛИТЕРАТУРЫ:}

1. Алексеевка [Электронный ресурс] // http://alekseevka63.ru.
2. Почвы Куйбышевской области / под ред. Г.Г. Лобова. Куйбышев: Куйбыш. кн. изд-во, 1984. $392 \mathrm{c}$.

3. Физическая карта Самарской области. Масштаб 1:500000. М.: Роскартография, 1994.

4. Государственная геологическая карта Российской Федерации (новая серия). N-38, 39 (Самара). Карта дочетвертичных образований. М. 1:1000000. СПб.: ВСЕГЕИ, 2000.

5. Государственная геологическая карта Российской Федерации (новая серия). N-38, 39 (Самара). Карта четвертичных образований. М. 1:1000000. СПб.: ВСЕГЕИ, 2000.

6. Атлас земель Самарской области / под ред. Л.Н. Порошиной. Самара: Московское аэрографическое предприятие, 2002. 101 с.

7. Почвенная карта Куйбышевской области. М. 1:300000. М.: ГУГК, 1988.

8. Плаксина Т.И. Анализ флоры. Самара: Самарский университет, 2004. 152 с.

9. Raunkiaer C. The life forms of plants and statistical plant geography. Oxford, 1934. 47 p.

10. Серебряков И.Г. Экологическая морфология растений: жизненные формы покрытосеменных и хвойных. М.: Высшая школа, 1962. 378 с.

11. Серебряков И.Г. Жизненные формы высших растений и их изучение // Полевая геоботаника. 1964. T. 3. С. $146-205$.

12. Серебрякова Т.И. Учение о жизненных формах растений на современном этапе // Итоги науки и техники. Сер. Ботаника. 1972. Т. 1. С. 84-169.

13. Бельгард А.Л. Степное лесоведение. М.: Лесная промышленность, 1971. $336 \mathrm{c.}$

14. Матвеев Н.М. Основы степного лесоведения профессора А.Л. Бельгарда и их современная интерпретация. Самара: Самарский университет, 2012. $128 \mathrm{c}$.

15. Красная книга Самарской области. Редкие виды растений, лишайников и грибов / под ред. Г.С. Розенберга, С.В. Саксонова. Тольятти: ИЭВБ PAH, 2007. $372 \mathrm{c}$.

16. Ассортимент древесных растений для зеленого строительства в Ростовской области / Б.Л. Козловский, Т.К. Огородникова, М.В. Куропятников и др. Ростов-на-Дону: Изд-во ЮФУ, 2009. 416 с.

17. Виноградова Ю.К., Майоров С.Р., Хорун Л.В. Черная книга флоры Средней России (Чужеродные виды растений в экосистемах Средней России). М.: ГЕОС, 2009. 494 с.

18. Деревья и кустарники СССР. Дикорастущие, культивируемые и перспективные для интродукции: в VII т. М., Л.: Изд-во АН СССР, 1949. Т. І: Голосеменные. 464 с.

19. Деревья и кустарники СССР. Дикорастущие, культивируемые и перспективные для интродукции: в VII т. М., Л.: Изд-во АН СССР, 1951. Т. ІІ: Покрытосеменные. $612 \mathrm{c}$.

20. Деревья и кустарники СССР. Дикорастущие, культивируемые и перспективные для интродукции: в VII т. М., Л.: Изд-во АН СССР, 1954. Т. III: Покрытосеменные. Семейства Троходендровые - Розоцветные. $873 \mathrm{c.}$

21. Деревья и кустарники СССР. Дикорастущие, культивируемые и перспективные для интродукции: в VII т. М., Л.: Изд-во АН СССР, 1958. Т. IV: По- 
крытосеменные. Семейства Бобовые - Гранатовые. $975 \mathrm{c}$.

22. Деревья и кустарники СССР. Дикорастущие, культивируемые и перспективные для интродукции: в VII т. М., Л.: Изд-во АН СССР, 1960. Т. V: Покрытосеменные. Семейства Миртовые - Маслинные. $545 \mathrm{c}$.

23. Деревья и кустарники СССР. Дикорастущие, культивируемые и перспективные для интродукции: в VII т. М., Л.: Изд-во АН СССР, 1960. Т. VI: Покрытосеменные. Семейства Логаниевые - Сложноцветные. 380 с.
Древесные растения в уличном озеленении поселка..

24. Матвеев Н.М. Биоэкологический анализ флоры и растительности (на примере лесостепной и степной зоны). Самара: Самарский университет, 2006. $311 \mathrm{c}$.

25. Плаксина Т.И. Конспект флоры Волго-Уральского региона. Самара: Самарский университет, 2001. $388 \mathrm{c}$.

26. Раков Н.С. Состав, структура и динамика адвентивной флоры Ульяновской области: дис. ... канд. биол. наук. Тольятти, 2012. 239 с.

27. Саксонов С.В., Сенатор С.А. Путеводитель по Самарской флоре (1851-2011). Флора Волжского бассейна. Тольятти: Кассандра, 2012. Т. 1. 511 с.

\title{
WOODY PLANTS IN STREET LANDSCAPING OF URBAN-TYPE SETTLEMENT ALEXEEVKA (SAMARA OBLAST)
}

\author{
Makarova Yulia Vladimirovna, candidate of biological sciences, \\ senior lecturer of Ecology, Botany and Nature Protection Department \\ Korchikov Evgeny Sergeyevich, candidate of biological sciences, \\ associate professor of Ecology, Botany and Nature Protection Department \\ Prokhorova Nataliya Vladimirovna, doctor of biological sciences, \\ professor of Ecology, Botany and Nature Protection Department \\ Samara National Research University (Samara, Russian Federation)
}

Abstract. Our results support that introducents ( $72,1 \%$ of 68 found species) might have important impact on ecosystem of urban-type settlement Alexeevka, Kinel Urban Okrug of Samara Region. The local community of woody plants include 68 species from 48 genera, 21 families, 2 classes (Pinopsida, Magnoliopsida) and 2 divisions (Pinophyta, Magnoliophyta). 30 species $(44,1 \%)$ of trees and 25 species $(36,8 \%)$ of bushes are dominant plants. They are basically summer-green, cross-pollinated (entomophilous) species, mesotrophes, mesophytes, sciogeliophytes and mezotermes, which fruits and seeds are spread by animals. Introducents (Eurasian, European-American and European types of habitats) were planted at different times. Rosaceae (21 species, 30,9\%) are well represented and the largest number of species contain genuses Populus (6 species), Rosa (4 species), Ulmus, Crataegus and Acer (3 species). We found seven rare species used in street landscaping: Juniperus communis L., J. sabina L., Crataegus volgensis Pojark., Tamarix ramosissima Ledeb., Cotoneaster melanocarpus Fisch. ex Blytt, Populus alba L. and Salix alba $\mathrm{L}$. The change in variability of local communities has significant implications for our ability to predict how the patterns of biodiversity and ecosystem function will respond to environmental changes.

Keywords: street landscaping; woody plants; aboriginal species; adventive species; introducents; rare species; life forms of plant; taxonomic analysis; chorological analysis; bioecological analysis; urban-type settlement Alexeevka; Kinel Urban Okrug; Samara Oblast.

УДК 595.768.12

\section{ОБЩАЯ СТРАТЕГИЯ РЕПРОДУКТИВНОГО ПОВЕДЕНИЯ ЖУКОВ-ЛИСТОЕДОВ (COLEOPTERA, CHRYSOMELIDAE)}

(C) 2017

Павлов Сергей Иванович, кандидат биологических наук, доцент кафедры биологии, экологии и методики обучения

Самарский государственный соџиально-педагогический университет (г. Самара, Российская Федераџия)

Аннотащия. В течение 1974-2014 гг. в условиях Самарской области изучалось репродуктивное поведение 25 фоновых видов жуков-листоедов (Coleoptera, Chrysomelidae). Стратегия репродуктивного поведения имаго (принципиально отличающаяся у особей противоположного пола) - комплекс (включающий более 60 типов локомоторных) поведенческих реакций, ориентированный на привлечение активного партнера (обычно самца), поиски и подготовку самки к финальному этапу репродуктивного процесса - к спариванию. После отрождения, имаго-самка проходит 5 этапов репродуктивной трансформации (питание созревания, привлечение самца видоспецифическим аттрактантом, спаривание, овуляцию, яйцекладку), сопровождающихся 18 типами поведенческих реакций. Имаго-самец в течение жизни преодолевает тоже 5 этапов (подготовку к спариванию и питание созревания, поиски самки, подготовку самки к спариванию, спаривание, финальную послебрачную чистку), обеспечиваемых почти 30 типами поведенческих реакций. Оценивается временной и физический ресурс выживания самки и самца (в разных ситуациях), а также - временные бюджеты дневной активности обоих полов на разных этапах их генерационного цикла. Рассматриваются случаи возникновения нестандартных репродуктивных ситуаций (или сбоев), которые объясняются вполне объективными причинами (ошибками в хемонавигации самцов, нарушением генетически запрограммированной последовательности стадий поведения, несогласованностью половых циклов партнеров). 